\title{
Et portræt af George Stephens - professor i engelsk ved Københavns Universitet og fremtrædende medlem af den engelske menighed i Danmark i en menneskealder
}

af lektor, Ph.D. Inge Kabell, Engelsk Institut, Københavns Universitet

I året 1834 døde professor T.C.Bruun ${ }^{1}$, den eneste (og første) lærer i engelsk ved Københavns Universitet. Til trods for at han nåede en meget høj alder (84 år), var han aktiv som lærer til det sidste. Først efter 17 års forløb besluttede Universitetet at finde en efterfølger for professor Bruun. Denne gang faldt valget på en englænder, George Stephens. ${ }^{2}$

George Stephens er født i Liverpool i året 1813 og død i København i 1895. ${ }^{3}$ Hans far var metodistpræst. Efter at have frekventeret et par privatskoler i England påbegyndte han sprogstudier og forhistoriske studier ved det netop oprettede universitet, "University College", i London. Allerede som ganske ung blev han grebet af studiet af de germanske oldsprog og af tanken om at opspore en eventuel fælles oprindelse for de skandinaviske sprog og hans eget engelske sprog, og han bestemte sig meget tidligt for at drage til Sverige og Danmark for her - om muligt - at finde frem til det engelske sprogs arketype, som han gav betegnelsen "the Scando-English dialect".

Stephens giftede sig som 21-årig med Maria Bennett (1808-96). Umiddelbart efter brylluppet drog de til Stockholm, hvor de bestemte sig for at blive. Denne beslutning hang måske til en vis grad sammen med det faktum, at George Stephens' bror (Joseph Rayner Stephens) allerede boede i denne by, hvor han, ligesom sin far, virkede som metodistpræst. George og Maria Stephens forlod først Sverige i 1851, og de år, de tilbragte dér, var nok de bedste i deres liv.

- George Stephens var en meget udadvendt og selskabelig natur, og han blev hurtigt engageret i mangt og meget inden for svensk kulturliv, samtidig med at han tjente 
til dagen og vejen som engelsklærer, som oversætter, som korrespondent til engelske aviser samt som forfatter. I forbindelse med sin undervisning skrev/udgav han for eksempel en lille svensk-engelsk ordbog i lommeformat og en del kommenterede skoleudgaver af engelske forfattere samt en meget kortfattet engelsk grammatik altsammen beregnet for svenskere uden særlige forudsætninger, der gerne ville tilegne sig det engelske sprog.

Han blev hurtigt gode venner med ledende svenske personligheder, såsom Geijer, Atterbom, Tegnér, Hildebrand og Hyltén-Cavallius, og sidstnævnte blev hans bedste ven; sammen skrev og udgav de to flere værker af historisk, folkloristisk og lingvistisk karakter. ${ }^{4}$

Til trods for at Stephens var udlænding, var han stærkt optaget af ideerne omkring Skandinavismen, ligesom han også, i artikler han sendte hjem til engelske aviser, gjorde sig til talsmand for, at Rusland skulle give Finland den ønskede uafhængighed. Som fortaler for en skandinavisk union - Skandinavismens kongstanke - var han til at begynde med modstander af Bernadottedynastiet i Sverige, men senere (1856) sagde han dog ja til at agere mellemmand mellem den svenske Kong Oscar og den engelske presse - mod et årligt vederlag på 1000 rigsdaler - måske fordi Kong Oscar, i modsætning til mange ledende politikere og kongelige personer i de skandinaviske lande, efterhånden kom til at se med sympati på en del af de ideer, der lå til grund for Skandinavismen.

Som allerede antydet befandt Stephens sig godt i Sverige, og i Dansk Biografisk Lexikon, 1902 (s. 409-12) kan man læse, hvordan hans mange lærde og patriotiske svenske venner, som alle delte hans interesse for Skandinavien i fortid og nutid, tit og ofte opsøgte ham i hans hjem i Stockholms gamle bydel, fordi de følte, at de i ham havde fundet en "åndelig" leder. I hans stue, hvor reoler dækkede væggene fra loft til gulv, samledes man, for eksempel for at høre en gammel folkevise blive foredraget af en af de tilstedeværende, mens Stephens selv lå udstrakt på gulvet som i trance - for så pludselig at springe op og klappe vildt af begejstring. I samme artikel er der en skildring af Stephens' udseende: han var som ung en slank mand, majestætisk og med et langt, kulsort skæg - ifølge ovennævnte kilde et tegn på, at der var spansk/fransk blod i ham.

Mens Stephens boede i Stockholm, var han ung, begejstret og idérig, men en del af de værker, som han planlagde at skrive sammen med sine venner, blev aldrig til 


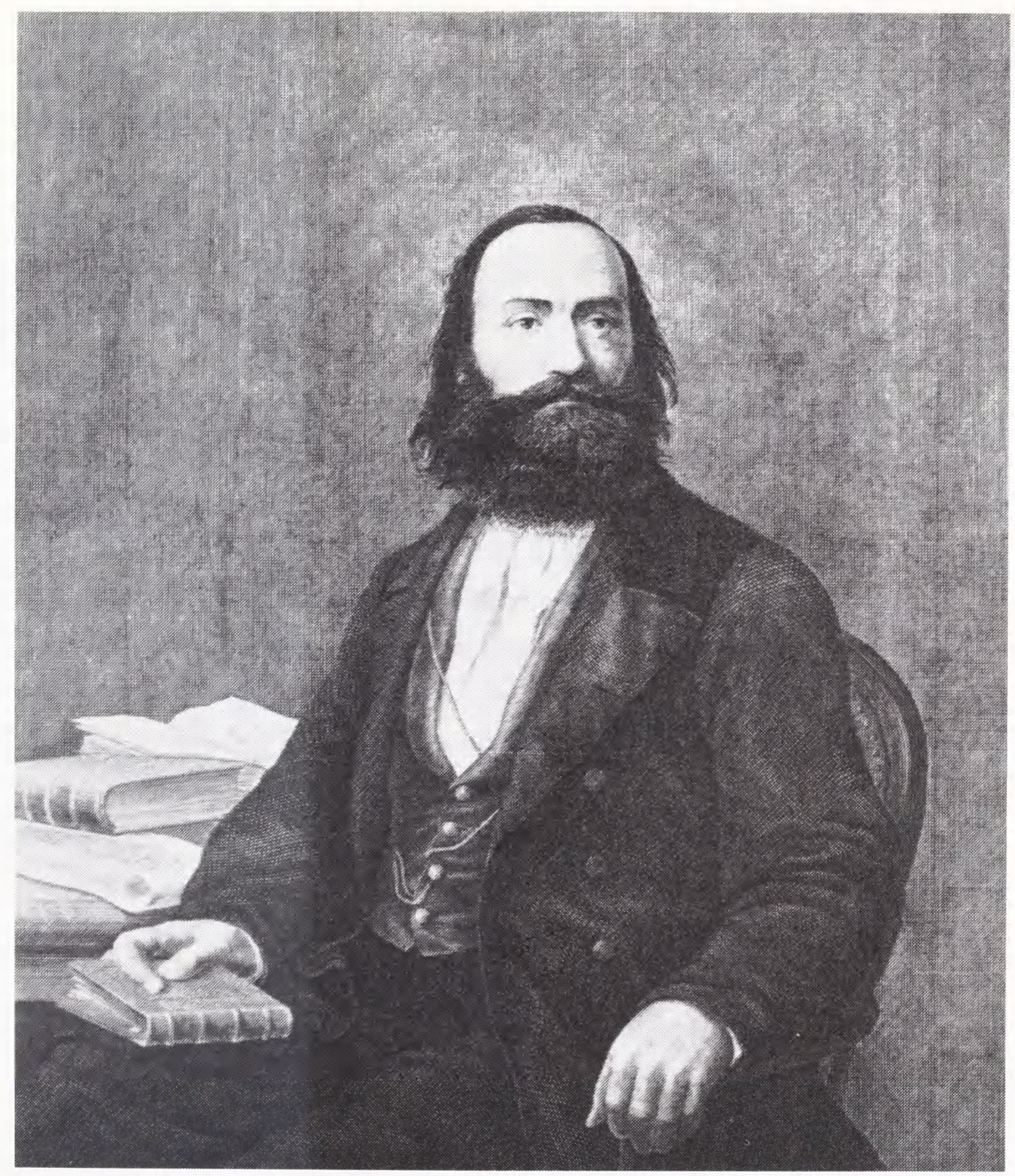

George Stephens. Stik af J. Mogens Petersen fra 1863.

noget, hvilket måske ikke var så galt endda; nok var deres ideer måske udmærkede, men når de skulle til at planlægge et kommende værk mere systematisk, løb de tilsyneladende snart ind i store problemer. Men det indsamlingsarbejde af gamle viser etc., som de havde foretaget - især i Sverige - og som skulle have dannet grundlaget for deres planlagte skrifter, var dog ikke spildt, idet disse gamle (skan'dinaviske) folkeviser, som de havde fundet frem til med så megen møje, senere blev overdraget til Svend Grundtvig, som inkluderede dem i sine berømte samlinger. 
Som nævnt ovenfor opslog Københavns Universitet i året 1851 et lektorat i moderne engelsk sprog og litteratur, som Stephens søgte og fik. Hermed opgav han sine folkloristiske studier, for, som han sagde, da jeg begyndte herpå, var vi få; nu er vi mange, og lad så de andre fortsætte arbejdet.

Stephens' ansættelse var oprindelig tidsbegrænset, men efter han var blevet dansk statsborger, opnåede han fastansættelse, og i 1855 blev han titulær professor. Han blev pensioneret fra Universitetet i 1893 og døde få år efter. Såvel han som hans kone ligger begravet i Danmark.

Et år efter at Stephens var blevet knyttet til Københavns Universitet, "fandt" man her en mindre sum penge, således at han kunne give et par timer mere - nu i oldengelsk - og blive aflønnet særskilt herfor. Allerede i 1860 slap disse midler dog op; men Stephens tabte ikke modet. Oldsprogene var og blev hans store interesse, og i 1865 annoncerede han en række forelæsninger over oldengelsk og middelengelsk sprog. Endelig i 1877 genoptog han sin yndlingsundervisning - kurser i læsning af oldengelske tekster. ${ }^{5}$ På det litterære område var det især Shakespeare, der interesserede ham; kun få andre engelske forfattere tog han op og blandt dem kun ganske enkelte samtidige.

En gennemgang af samtlige lektionskataloger fra perioden 1851-93 viser følgende om hans undervisningsaktiviteter i disse mange år: Almindeligvis underviste han fire timer om ugen, og det var ikke usædvanligt, at han brugte 2-3 semestre på gennemgang af ét Shakespeare-skuespil. Skønt hans udvalg af forfattere var stærkt begrænset, må det betragtes som noget positivt, at han meget sjældent gennemgik samme tekst to gange. I årenes løb udbød han som forelæsningsemner mere end 20 Shakespeare-skuespil, men kun Macbeth blev gentaget - en enkelt gang. Ud over at forelæse over hvad vi i dag vil betegne som de "ægte" Shakespeare-værker, beskæftigede han sig også med et stykke af mere tvivlsom oprindelse, nemlig Henry VIII. Herudover viste han interesse for et par dramatikere, der var samtidige med Shakespeare, og som måske arbejdede sammen med ham - eller med hinanden. Der tænkes her på Philip Massinger og John Fletcher. Stephens brugte således seks semestre (1870-73) på en diskussion af førstnævntes skuespil og to på det skuespil, som han kalder The Two Noblemen, men som vel må være identisk med The Two Noble Kinsmen, som antages at være skrevet af Fletcher - eventuelt i samarbejde med Shakespeare. De eneste andre engelske forfattere - og en enkelt amerikansk - 
som han forelæste over i de mange år var: Chaucer (i 1851-2), Spenser (i 1852), Longfellow (i 1857-8), Milton (7 semestre i begyndelsen af 60erne), Swinburne (i 1876-7) og Marlowe (i 1888).

Det er karakteristisk for Stephens, at de af ham anbefalede udgaver af de værker, som han udbød til gennemgang, altid var de allernyeste. Dette gælder også hans undervisning i old- og middelengelsk. Engang (i efteråret 1859) meddelte han endda, at han ville bruge Grundtvigs udgave af Beowulf, hvis den da var klar fra trykkeren! Dette tyder på, at han var en samvittighedsfuld lærer med et vågent øje for nye udgaver også af gamle tekster, når de dukkede op i England eller Danmark. Gennemgangen af lektionskatologerne har også afsløret, at han aldrig forsømte noget semester i alle disse mange år.

Hvad angår hans lektioner i old- og middelengelske emner bestod de fortrinsvis af tekstlæsning. I den forbindelse bemærker man, noget rystet, at han brugte 10 år på en gennemgang af et enkelt evangelium. I nogle semestre gav han dog også sproghistoriske forelæsninger, som nok var af en noget bredere karakter - i 1853 diskuterede han, for eksempel Rasmus Rasks angelsaksiske grammatik ${ }^{6}$ og i 1856 Trench's The Study of Words, som udkom i 1853.

Det meste af den tid Stephens virkede i København, var han den eneste engelsklærer ved Universitetet; i hans senere år dukkede der imidlertid også andre lærere op, der helt eller delvis inkluderede engelske emner i deres undervisning. Den første, der skal nævnes, er Georg Brandes, som - ikke uventet - kom ind på den engelske litteratur i sine berømte forelæsninger "Hovedstrømninger i det 19. Aarhundredes Litteratur", som begyndte i 1871, og som senere, i 1874, fulgtes af "Naturalismen i England", hvor emnet, som titlen viser, uddybedes nærmere.

En halv snes år før Stephens trak sig tilbage, må man fra universitetets side have erkendt - i forbindelse med indførelsen (i året 1883) af sproglig-historisk skoleembedseksamen - at de engelskstuderende, som jo nu primært skulle ud og være engelsklærere i den højere skole, udover hvad Stephens kunne give dem, måtte tilbydes en målrettet, praktisk orienteret undervisning i discipliner som oversættelse, mundtlig sprogfærdighed og fonetik. De første lærere, som kom til at tage sig af disse fag - først som privatdocenter - var Adolf Hansen og Otto Jespersen. På dette tidspunkt stod Stephens som repræsentant for "den gamle skole", mens Otto Jespersen (1860-1943) var den unge, nye og progressive lærer med ideer, man aldrig 
havde hørt om før. Det er derfor ikke så mærkeligt, at forholdet mellem Stephens og Jespersen blev temmeligt anspændt - for at sige det mildt, og divergenserne mellem dem blev vel yderligere forstærket derved, at Jespersen også begyndte at undervise i oldengelsk. ${ }^{7}$ Jvfr. nedenfor.

Udover at mødes med sine studerende på universitetet indbød Stephens dem også til at komme hjem til sig; hver eneste onsdag aften i de 42 år, hvor han virkede som lærer her i landet, holdt han åbent hus fra kl. 7 til kl.10. Herved fik de studerende sikkert en kærkommen lejlighed til at øve deres praktiske engelske sprogfærdighed under mere tvangfri former. ${ }^{8}$

I en interessant lille bog The Traveller's Handbook to Copenhagen and Its Environs, ${ }^{9}$ som udkom i 1853 under pesudonymet "Anglicanus", er der en kort samtidig beskrivelse (s. 46) af Stephens' virke i Danmark omkring midten af forrige århundrede: "In the Autumn of 1851 an English Lectureship was established [at the University of Copenhagen], and in the following year an Old-English (Anglo-Saxon) Lectureship, both which are ably filled by George Stephens, Esqr." Forfatteren bag pseudonymet var Robert Stevenson Ellis, der virkede som præst ved den britiske legation i København i en meget lang periode, 1834-1883, og som skulle komme til at arbejde tæt sammen med Stephens i forbindelse med planlægningen og opførelsen af St. Alban’s Church, den engelske kirke ved Langelinie i København, jvfr. nedenfor.

Som det var tilfældet i Sverige, ser det også ud til, at Stephens i Danmark brugte sine evner og kræfter på så mange forskellige områder, at han vel sjældent rigtig fik mulighed for at gå i dybden med et problem - med undtagelse af hans store værk om runerne. Generelt var hans videnskabelige produktion meget stor. De forskellige biografiske værker ynder at beskrive Stephens - og hermed hans interesser - ved hjælp af tre betegnelser: han var, siger de, samler, folklorist og runolog. Herved adskilte han sig på ingen måde fra sine europæiske samtidige i videnskabens verden, idet netop disse "emner" på den tid vandt genklang hos mange. Blandt de ting han samlede på, kan nævnes frimærker, kunst, danske oldsager, håndskrifter og inkunabler. Den anden betegnelse "folklorist" skal især ses i relation til hans aktiviteter i Sverige og er derfor ikke relevant for den danske side af hans liv. Den tredie og sidste betegnelse "runolog" er i en dansk sammenhæng uden tvivl den vigtigste, især da den er nøje forbundet med hans hovedværk, The Old Northern Runic Monuments I-IV (hvoraf bind I-III udkom i Danmark og bind IV i Sverige - i tidsrummet 


\section{THE OLD-NORTHERN}

\section{R U NIC II ON U II E N TS}

OF SCANDINAVIA AND ENGLAND,

NOW FIRST

COLLECTED AND DECIPHERED

BY

GEORGE STEPHENS, ESQ., F. S. A.,

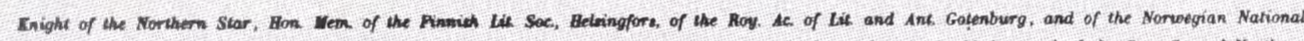
Monument Assoc, Christiania; Fellowe of the Roy. Soc, of Sciences, Opeala, of Che Roy. Ac. of thist and Ant, Stockholm, and of the Roy. Soc. of Northern

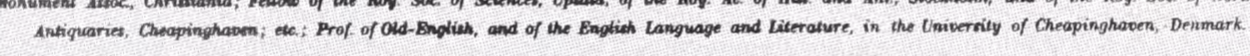

WITH MANY HUNDREDS OF FACSIMIES AND ILLUSTRATIONS, PARTLY IN GOLD, SILVER, BRONZE AND COLORS; RUNIC ALPHABETS; INTRODUCTIONS; APPENDICES; WORDLISTS, ETC.

\section{0 L. I.}

LONDON.

KÓBENHAVN.

JOHS RUSSELL SMITH. MICHAELSEN ANH TILLGE.

PRIXTRD RY H, H. THIBLF.

$1866-67$ 
1866-1901) og, noget fjernere, med hans forelæsninger over oldengelsk og middelengelsk.

Denne interesse for den skandinaviske fortid var en interesse, som deltes ikke kun af mange skandinaver men også af en del af hans engelske landsmænd, som for eksempel forfatterne George Borrow, Thomas Carlyle og William Morris - og i en bredere forstand også af et stort antal forskere og forfattere over hele Europa. Om hans specielle forhold til tyske forskere, jvfr. nedenfor.

Ovennævnte værk, hans tour-de-force, kan ses på Det kongelige Bibliotek i København. Det, der først påkalder opmærksomheden, er simpelthen bøgernes størrelse. Der er fire bind ialt - i foliostørrelse - som tilsammen omfatter mere end 1500 sider. Deres ydre fremtræden er særdeles smuk og roses da også stærkt af hans ellers hårdeste kritiker, L.F.A. Wimmer, ${ }^{10}$ som siger således:

"Det er et i flere henseender mærkeligt, længe med længsel af sprog- og oldtidsforskere imødeset værk, hvis første halvdel, som jeg i det følgende nærmere skal omtale, [der] nu foreligger offentligheden. Allerede ved sin hele ydre form, sin höjst elegante udstyrelse må det vække opmærksomhed som et af de pragtfuldeste skrifter, der er udkomne i vort fødeland; det ville heller ikke have været forfatteren muligt at lade det udkomme i denne form, hvis der ikke både offentlig og privat (navnlig fra det danske videnskabernes selskab) var ydet ham bistand. Når jeg nu med få ord skulde udsige en dom, som jeg senere nærmere skal begrunde, om den foreliggende del af dette værk, da må jeg yde forfatteren tak og anerkendelse for den store flid og den utrættelige iver, hvormed han har samlet alle disse mindesmærker i fortræffelige afbildninger, såvidt det lod sig göre efter originalerne selv; det er navnlig for den nordiske sproghistorie af yderste vigtighed at have alle disse indskrifter samlede i nöjagtige, naturtro gengivelser;...", "De ældste nordiske Runeindskrifter" i Aarbøger for Oldkyndighed og Historie, 1867, (s. 1).

Men Wimmer fortsætter - nu mindre positivt:

"Med rette kan man på forfatteren anvende de ord af den romerske digter, jeg har brugt som motto: han har samlet en rig skat, som eftertiden vil vide at drage nytte af. Selv har prof. Stephens derimod ikke kunnet benytte sin samling således, at nye og vigtige resultater derved er vundne for videnskaben; ...” (s. 2).

Af forskelige årsager skal dette værk ikke diskuteres nærmere her. Først og fremmest ville det være nærmest endeløst at nærlæse det, og en saglig vurdering af 
indholdet ville kræve en specialviden, som nærværende forfatter ikke er i besiddelse af. For det andet har eksperter allerede diskuteret det og draget så negative konklusioner, at der næppe kan være meget at tilføje. (Man kan måske sige, at det på mange punkter var forældet, inden det udkom, og at det sikkert primært har haft værdi for senere tiders forskere på grund af de meget fine illustrationer, der findes $\mathrm{i}$ det). Et par bemærkninger, fremsat af Wimmer i ovennævnte artikel skal dog citeres blandt andet for at vise, hvor barsk man som forsker kunne (kan?) angribe en fagfælle. Wimmers udtalelser vil hver gang blive fulgt af Stephens gendrivelser, som stammer fra hans artikel, "Candidat L.F.A.Wimmer om de oldnordiske Runeindskrifter", som er at finde i samme årbog, op.cit., som Wimmers anmeldelse. Wimmer lægger således ud:

"Men sproghistorie, dens resultater, dens anvendelse - alt dette er for prof. Stephens terra incognita; for os andre er der i alle sprog bestemte love, hvorefter de enkelte fænomener må forklares; der er regelmæssige, bestemte lydovergange, som kun den historiske sprogforskning kan stille i det rette lys. Når derfor prof. Stephens begynder det her omtalte afsnit af sin indledning med de ord: 'Much of the argument in these pages depends on the occurrence of forms and words unknown to the Dictionaries and Grammars. But this is the most shining proof, in my eyes, of the correctness of my readings', så giver jeg professoren ret i denne påstand $\mathrm{i}$ dens almindelighed, men tilföjer dog straks den indskrænkning: ' hvis disse ord og former forresten har sproghistorisk rimelighed." (Wimmer, s. 4). - -

Hertil svarer Stephens:

"Jeg har intetsteds nægtet disse "lydoverganges" tilstedeværelse. Jeg har kun forlangt, at de skulle bruges hvor de kendes, og med hensyn til hvad man kender, og ikke, hvor de ere ubekendte, eller med hensyn til hvad man ikke kender." (Stephens s.193). - -

Wimmer fortsætter sit angreb:

"Ny og interessant er den opdagelse, forfatteren tilföjer i en note, at Rask, fordi han erklærede Engelsk for germansk, [ $\left.{ }^{11}\right]$ har fremkaldt 'Slesvig-Holsteinismen'!! 'I need not add, that Rask's theory has had strange and disasterous consequences. Taken up by Jacob Grimm and his German followers, it has materially shaped and 'assisted the absurdities and iniquities of modern 'Slesvig-Holsteinism'... - So much evil may flow from one rash assumption!' Alt det er Rasks skyld!! Det havde hverken 
han eller hans disciple i Danmark nogensinde drömt om, at det tilsidst skulle blive opdaget, at han var den egentlige ophavsmand til 'Slesvig-Holsteinismen'." (Wimmer, en note s.8). - -

Og Stephens svarer lidt spagfærdigt:

"Men det har jeg nu ikke sagt. Jeg har sagt (s. 29 i mit værk) at Rasks teorier i de skikkelser, de fik hos J. Grimm, hos Kejser, og hos Munch, bleve brugte som støttepunkter for Slesvigholsteinismen. Det er ikke at kalde Rask 'den egentlige ophavsmand til slesvigholsteinismen'." (Stephens, s. 195-6). - -

Wimmer fortsætter mere detaljeret:

"Prof. Stephens har slet ikke lagt mærke til, at han i sin iver kommer til at bevise altfor meget og derfor slet intet beviser. Det er en gennemgående fejl hos ham, at han ikke forstår at skælne mellem den virkelige lyd og lydbetegnelsen." (Wimmer, s.18). (Dette er en kommentar til en påstand fremsat af Stephens, der gik ud på, at man godt på een og samme runesten kunne finde runer tilhørende forskellige dialekter). - -

Hertil svarer Stephens:

"Min lære er - med hensyn til de ældste nordiske lige så vel som med hensyn til de egentlig skandinaviske runeindskrifter - at vi ikke kunde lænkebinde disse gamle sager til nogen pedantisk "correct" retskrivning, at vi netop må skelne mellem lyd og tegn. Og jeg beviser dette ved henvisninger til mindesmærker alle andre steder, classiske og ikke classiske." (Stephens, s. 193). - -

I den sidste del af artiklen går Wimmer endnu mere i detaljer og diskuterer og gendriver praktisk talt alle de teorier, som Stephens fremsætter. Han afslutter dog sin anmeldelse på et høfligt plan:

"Hermed slutter jeg disse bemærkninger om de ældre runeindskrifter og prof. Stephens værk; jeg har ikke kunnet erklære mig enig med prof. Stephens i meget; men jeg sender ham endnu engang til afsked min tak, fordi han har gjort disse ærværdige minder fra vore fædres tid let tilgængelige for videnskabsmændene; hans værk vil altid blive et kildeskrift i denne videnskabsgren..." (Wimmer, s.63). - -

Man kan ikke undgå at få den tanke, at Stephens' had til tyske forskere og deres teorier, som gennemsyrer så meget af hans arbejde, var politisk snarere end videnskabeligt baseret. Han følte sig utvivlsomt som en god patriotisk dansker, og efter at Danmark havde lidt et så frygteligt nederlag til tyskerne (prøjserne og østrigerne) i 


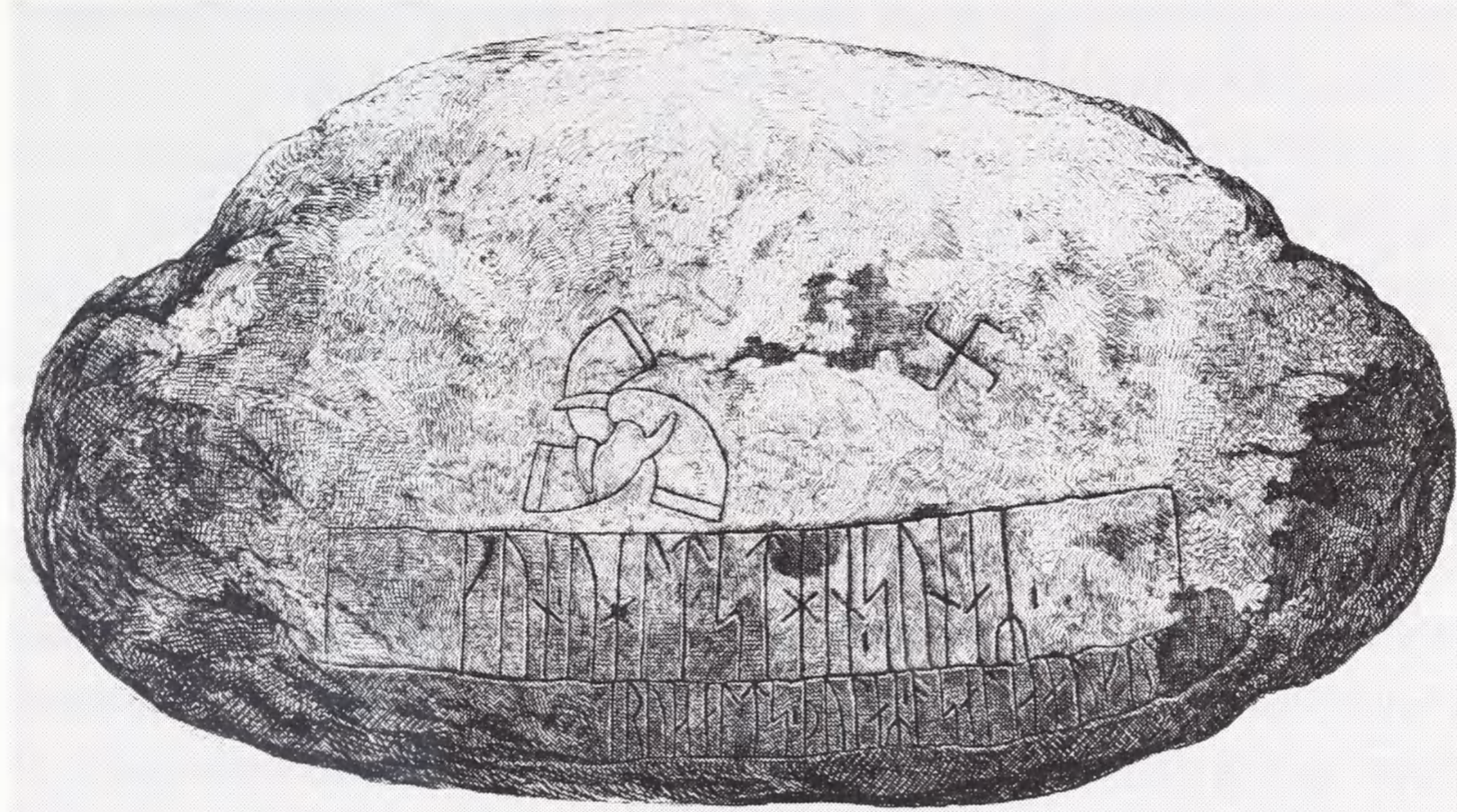

Snoldelev-stenen fra 7-800 f.v.t. Gengivet efter The Old-Northern Runic Monuments of Scandinavia and England. Vol. I. 1866-67.

1864, har han set en anledning til at "angribe" repræsentanter for disse nationer på et område, hvor han følte sig kompetent; hvad han gjorde var i sig selv forståeligt og ærefuldt, men - fra et moderne synspunkt - ret overdrevet, og i forbindelse med forhistoriske- og middelalderstudier helt irrelevant og nærmest absurd.

Som et resultat af sine oldengelske studier udgav Stephens (i 1860) en facsimile udgave af et oldengelsk digt, "Waldere", som man netop havde fundet i Det kongelige Bibliotek i København. Hans nærmest overdrevne interesse for fortiden fik ham endog til at danne et nyt "gammelt" navn for København, "Cheapinghaven", som han ofte anvendte i forbindelse med offentliggørelsen af sine egne værker.

I sin selvbiografi, Livsdagen lang, 1947, s. 39, tegner Louis Bobé (født 1867) et portræt af Stephens, som han husker ham. Bobé traf ham for første gang, da han selv var ca. 15 år gammel i forbindelse med en elementær optagelsesprøve, han skulle aflægge. Mærkeligt nok blev denne prøve varetaget af professorer ved Københavns Universitet, som naturligvis var overkvalificerede hertil, og som for de flestes vedkommende hadede dette arbejde - som de kun påtog sig for pengenes skyld, usselt lønnede som de var. Om Stephens siger Bobé:

"George Stephens, Professor i engelsk Sprog og Litteratur, var blandt Universitetslærerne i min grønne Ungdom den mest dekorativt groteske Skikkelse med sit 
vældige, graanede Skæg ned over Brystet og Haarmanke, der faldt i Krøl ned ad Nakken, Skotte af Byrd, født i Aaret for Slaget ved Leipzig og fra 1855 Professor i Engelsk. Saa man ham vandre i Gaderne i Slængkappe og med den mægtige Bulehat lignede han nærmest en ossiansk Bonde eller en Skønaand eller Kunstner fra 1848. Runeforskningen og Tanken om et scando-gotisk Fædreland opfyldte hans Tilværelse.

For alle Præliminarister, der ved Examensbordet var blevet vraget af Steen og Oppermann, gjaldt Stephens som et Nødanker for det synkende Skib. Han opfattede det selv som en Mission, ved sin uforlignelig milde Examination $\left[{ }^{12}\right]$ at rejse Modet hos den forknytte Examinand efter den ilde Medfart. Betegnende i saa Henseende er den rørende, men sandfærdige Historie om de to Islændere, der umiddelbart efter bestaaet Prøve skulle op til deres Fødeø med Skibet "Laura”. Den ene havde klaret sig helt pænt med et mg i Engelsk, den anden - han maa have været ualmindeligt smaat kørende - havde kun faaet "godt" og manglede et Póæng eller to for at kunne bestaa. De to "Fostbrødre" begav sig da efter Examinationen ud i Stephens' Privatbolig og bad Hr. Prófessoren ombytte Karaktererne. Rørt over dette ædle Brodersind opfyldte Stephens deres Begæring og indbød dem endog til at drikke Te. Senest husker jeg Stephens fra en Grundlovsfest, da han, ledet af Formanden for Students debating club, Kancelliraad Damm, gik i Spidsen for det konservative Partis Opmarch og hilstes som en Stærkodder af Mængden med Hurraraab, hvilke han besvarede med sære gutturale Lyde og uforstaaelige Tilraab i sin mærkelige Sprogblanding af Engelsk og Dansk. En mere konservativ Mand end Stephens kan ikke tænkes. To saa forskellige Begreber som Fritænkeri, for ikke at nævne det frygtelige Ord Atheisme, og Fonetik opfattede han som lige vederstyggelige Aandsrørelser. Georg Brandes betegnede han som "the antichrist", og Fonetikeren Otto Jespersen var ham som Peber i Næsen."

At Jespersen absolut heller ikke var en ynder af George Stephens er allerede kort nævnt ovenfor. I sin selvbiografi, op. cit. fortæller Jespersen dels om Stephens' undervisning, som han oplevede den, dels om den eksamination Stephens underkastede ham i 1887, da han afsluttede sine studier:

"Av dosenten i mit andet bifag, Stephens lærte jeg heller ikke noget. Han holdt stadig to rækker forelæsninger, hver på een time ugentlig. I den ene gennemgik han de oldengelske evangelier på et ret uvidenskabelig måde; jeg hørte kun et par timer. I den anden tog han Shakespeares stykker, heller ikke dem gik jeg hyppigt til. Jeg 
husker tydeligt een forelæsning, hvor han under gennemgangen av Macbeth kom til sætningen: "Glamis hath murder'd sleep". Hele timen formede sig da som en meget teatralsk præken med mange gestus om temaet: forbryderen kan ikke sove roligt, men vi som ikke har begået noget mord, kan rolig gå i seng i fortrøstning til at vi enten skal vågne op til et bedre liv hisset eller til et fortsat roligt liv $\mathrm{i}$ denne verden. Og med denne sluteffekt tog han sin store hat, der lå på katedret, og vandrede majestætisk ud av salen." (s. 46-47). - -

"Den mundtlige examen i engelsk var ikke uden en viss komik. Først blev jeg hørt i et stykke av en læst forfatter, så skulle jeg prøves i et stykke ulæst; hertil hade Stephens valgt et digt af Keats, men han blev højlig forbavset over at jeg ikke hade bog med hertil: det danske examenssystem var ikke gået op for ham. Det viste sig at han heller ikke hade meddelt sensorerne, Ad. Hansen og rektor Hauch, hvad for en bog der skulde benyttes, så der var kun ett exemplar for os alle at se i. Da det var overstået så’ Stephens på sit ur og sa at nu måtte han gå, da han skulde til et møde, hvortil Ad. Hansen bemærkede at kandidaten jo også skulde ha en karakter i litteraturhistorie, så Stephens blev jo nødt til at stille et spørgsmål og la mig fortælle lidt (om Marlowe)." (s. 48). ${ }^{13}$

Ligesom i Sverige dyrkede Stephens også i Danmark mange interesser af privat karakter. Når han havde gjort sin pligt som lærer og forsker, optrådte han ofte i sin rolle som medlem af den engelske menighed, en rolle, som han gik langt mere op i end nogen kunne forvente. Netop i den sidste halvdel af det 19. århundrede var denne menighed ude i store vanskeligheder. I en meget lang årrække havde der været en engelsk koloni og en engelsk-talende menighed i Danmark med centrum (oprindelig i Helsingør men siden) i København, hvortil der var knyttet en engelsk præst, hvis formelle tilhørssted dog var den britiske legation i den danske hovedstad. ${ }^{14}$ De forskellige steder, som herboende englændere var blevet og stadig blev henvist til for at dyrke deres religion, var særdeles ydmyge og kunne næppe kaldes kirker, og som tiden gik, opstod der da også et mere og mere udtalt ønske blandt den stadig større og mere indflydelsesrige menighed om at få sin egen, rigtige kirkebygning. Allerede i 1853 blev der nedsat en byggekomité, men der skulle gå mere end 30 år, før St. Alban's Church ved Langelinie kunne indvies. ${ }^{15}$ Det havde været 'strengt og hårdt at nå så langt, og en af dem, der havde trukket det hårdeste læs, var nok George Stephens. 


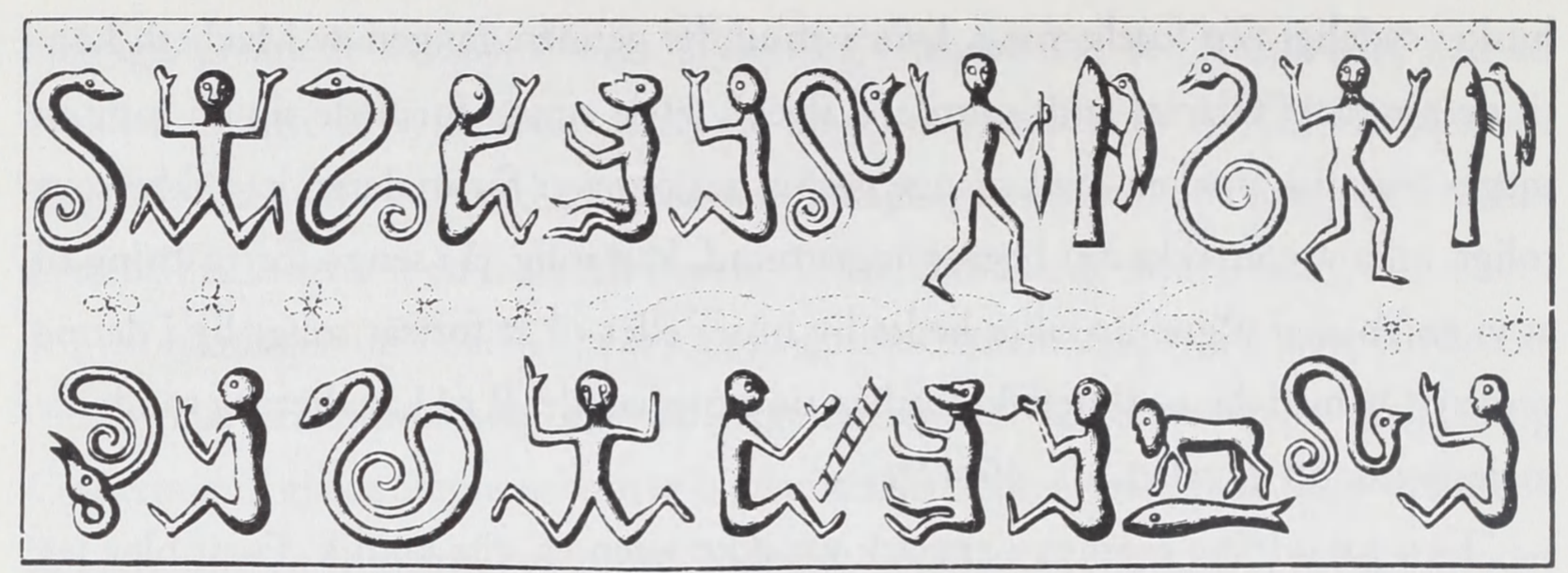

Tegninger af det guldhorn, der blev fundet ved Gallehus i 1639. Gengivet efter The Old-Northern Runic Monuments of Scandinavia and England. Vol. I. 1866-67.

Jarvis indleder således om Stephens' indsats:

"One man in particular stands out boldly from the background of general effort, to wit, Professor Stephens, $\left.{ }^{16}\right]$ not that he was alone in the fight, but he was undoubtedly one of the first to gird up his loins, and he took a leading part throughout." (Jarvis s. 54).

Dette kirkeprojekt blev første gang officielt nævnt i en annonce indrykket i flere engelske aviser (i februar 1853), hvori man opridsede baggrunden for planerne og bad om økonomisk støtte. 5 personer ${ }^{17}$ - heraf 4 med engelske navne, men alle bosat i Danmark - stod som underskrivere. Desværre var der overhovedet ingen positive reaktioner på denne henvendelse til den engelske offentlighed.

Næste skridt (i december 1858) var en formel ansøgning til den danske regering, udfærdiget af et nyt medlem af menigheden, Mr.Owen, og protokolmæssigt fremsendt via den britiske legation. Som sekretær for komiteen tilfaldt det Stephens at udfærdige følgebrevet, som er et typisk eksempel på hans dramatiske og malende stil. At få en "rigtig” kirke er så betydningsfuldt for menigheden, siger han, fordi:

"our late and present make-shifts (for they cannot be called churches) have long been, and are, a standing scandal to our Faith, our Country, and to the Embassy to which the Chaplaincy is attached. Both in print and out of it, the finger of scorn has long been pointed at us. We are now endeavouring to wipe away this blot, to remedy a state of things highly melancholy and highly inconvenient." (Jarvis s. 57).

Endnu en gang talte man for døve øren, og der gik en rum tid, før et yderligere forsøg blev gjort (i1864). Denne gang skrev Ellis og Stephens sammen et brev til hans Kongelige Højhed Albert Edward, Prince of Wales, hvori de fremførte det 


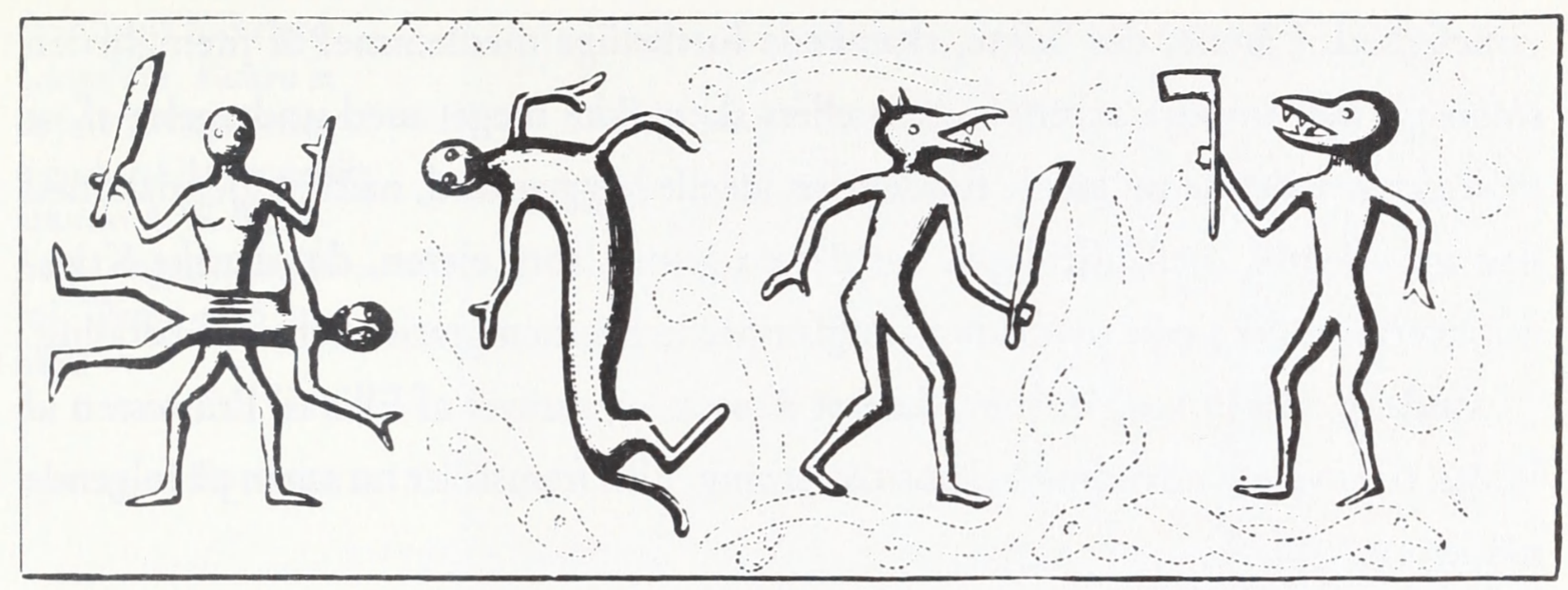

urimelige i, at andre fremmede trossamfund såsom katolikker, den ortodokse russiske kirke, jøder og metodister havde deres egne kirkebygninger i Danmark, mens herboende englændere ikke havde noget værdigt sted at dyrke deres religion, et sted der var "suitable for the decency and order required by the beautiful Ritual of the English Church.” Som det var nu, måtte de nøjes med “an ugly, bald, and highly inconvenient building belonging to the Moravian Brothers" - som de endda måtte betale dyrt for at leje. (Jarvis s. 58).

Før dette brev blev skrevet, havde menigheden anmodet den danske regering om at få tildelt en byggegrund; anmodningen blev afslået, fordi menigheden ingen penge havde. Men årsagen til, at man ikke havde kunnet skaffe penge, var netop den, at man ikke havde nogen grund at bygge på endnu. Folk ville ikke give løfte om økonomisk støtte, førend de kunne se, at der var realiteter bag planerne. Anmodningen til Prinsen af Wales var derfor delt i to dele. Man bad ham om enten at bruge sin indflydelse over for den uvillige danske regering for at få den til, trods alt, at skænke englænderne den byggegrund, de ønskede, eller simpelthen selv at stille en så stor sum penge til rådighed for menigheden, at den danske regering under disse ændrede forhold ville se mere velvilligt på hele projektet. Men atter en gang var svaret negativt; hvis menigheden selv kunne tilvejebringe en rimelig stor sum penge, ville Prinsen også yde sit, men kun hvis han følte sig sikker på, at det hele kunne blive til noget.

Men i 1868 hændte der for en gangs skyld noget positivt. I det år forlod den engelske købmand og tidligere konsul i Helsingør, Francis C. Macgregor, Danmark 'for altid, og ved den lejlighed overlod han byggekomiteen 1000 Rigsdaler, som skulle investeres på bedste vis og være disponible den dag planerne kunne blive til 
virkelighed. I årene, der fulgte, skænkede forskellige medlemmer af menigheden større og især mindre summer, men ellers skete ikke meget med undtagelse af, at man tilsyneladende nu havde fundet den ideelle byggegrund, næsten identisk med den nuværende, men uheldigvis var det en grund, som ejeren, det danske Krigsministerium, ikke ville overlade til englænderne hverken gratis eller mod betaling.

Endelig i 1879 kom et brev, dateret 9. sept. og skrevet af Ellis til Prinsessen af Wales, til at vende udviklingen i positiv retning. Ellis fremstiller nu sagen på følgende måde:

"It is now said that a plan is in contemplation for reclaiming a portion of ground from the Harbour (between the Custom House and the present Quarantine House) which is to be filled in, so as to join the Long Line; the stripe nearest the Sound to be employed for Custom House purposes; whilst the reclaimed space between that stripe and the present Long Line is to be laid out as a garden or plantation.

In this case, the ardent wish nourished for so many years by the British congregation could at once be carried out, if His Majesty the King should be pleased to allow a small but ornamental Church to be erected on a section of the land intended for planting..." (Jarvis s. 64).

Selvom Jarvis siger, at det var Ellis, der skrev dette brev, er der tre underskrivere, af hvilke den ene er Stephens, og man fristes til at tro, at denne må have forfattet det sidste afsnit, da det afviger væsentligt fra de andre dele af brevet ved sin specielle stil, så typisk for Stephens. Hans appel til Prinsessen af Wales, den tidligere danske Prinsesse Alexandra, lyder således: “Denmark's daughter is England's future Queen. But England's venerable and Apostolical Church is here homeless and helpless. Elsewhere on the Continent our Holy Religion has not been unfriended by the local authorities, like as the Continental Churches have been variously favoured in Great Britain.

In our days Atheism on the one hand and Romanism on the other, leave no stone unturned to further what must end in wild anarchy or degrading superstition, both equally dangerous to the Family and the State. Christian Princes may well use their influence in favour of pure Religion and social Order." (Jarvis s. 645).

På en eller anden måde må svaret på dette brev (gengivet af Jarvis s. 66-7) være blevet positivt opfattet, selvom det måske er lidt svært umiddelbart at se hvorfor. 
St. Alban's Kirke ved Langelinie. Kirken er opført 1895-87 efter tegning af den engelske arkitekt A.W. Blomfield i engelsk/gotisk stil. Tårnet er $45 \mathrm{~m}$ højt.

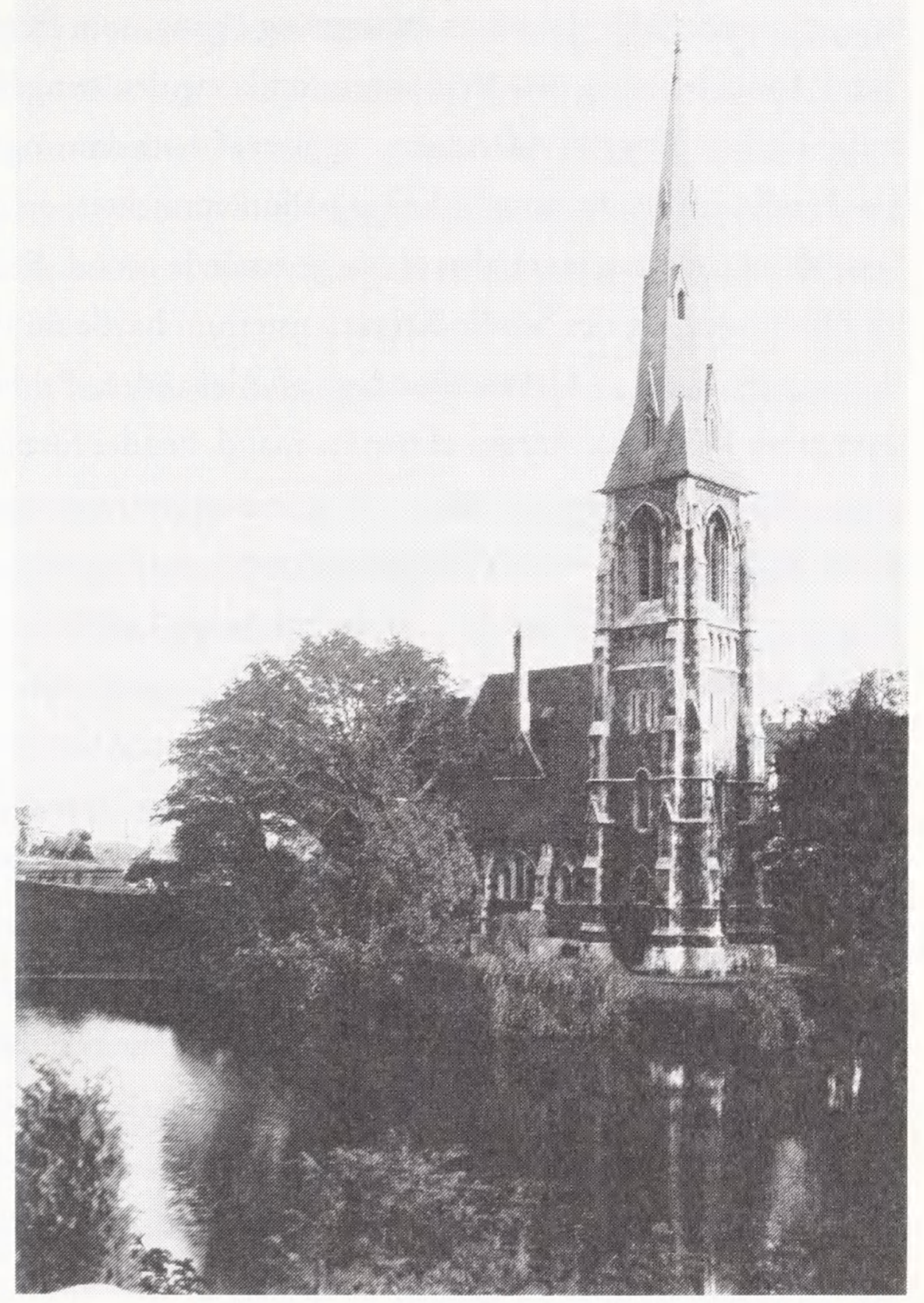

Essensen af det er, at Prinsen og Prinsessen lover at skænke en stor sum penge, når planerne har taget form, og menigheden har købt eller fået en passende grund. Hvad angår den foreslåede grund, mener de ikke, at den nogensinde kan erhverves, og de foreslår, at byggekomiteen prøver at finde en anden.

I de følgende år blev komiteen udvidet med flere nye medlemmer, som gik i gang med arbejdet med stor iver. Endog kvinder ${ }^{18}$ tog nu aktivt del, f.eks. ved at arrangere bazarer, og efterhånden stod der en pæn stor sum på byggekontoen.

Så oprandt en meget vigtig dag (17. september, 1883), en dag, hvor et særdeles prominent selskab aflagde besøg i Danmark i forbindelse med et krydstogt med Pembroke Castle. Blandt de besøgende var "the right honourable W.E. Gladstone" 
og "Alfred Tennyson, the poet Laureate", og da disse fornemme gæster hørte om byggeplanerne, blev der sat en indsamling i gang, som fremskaffede yderligere 70 pund. Dette besøg og hele stemningen omkring den kongelige familie, den danske konge og dronning på Fredensborg, omgivet af deres døtre og kongelige svigersønner, havde nok også en gunstig virkning på kirkeprojektet, og omsider nåede man da frem til enighed angående den så længe attråede grund. Et tidsubegrænset lejemål blev løsningen, og det danske Krigsministerium havde nu ikke flere indvendinger.

Grundstenen til kirken blev lagt af Alexandra, Prinsessen af Wales, d.19. september 1885 i nærværelse af hendes mand, hendes forældre og hendes søster og svoger (Zarinaen og Zaren af Rusland) og mange andre - kongelige og ikke-kongelige. På gæstelisten finder man naturligvis også professor Stephens' navn. Efter ceremonien var der frokost for alle på Osborne, som havde bragt det engelske selskab hertil. (Jarvis, s. 82-6). To år efter at grundstenen var lagt, blev kirken indviet, d. 27. september, i nærværelse af mange af de samme personer, som havde været til stede to år før. Festlighederne varede flere dage og kulminerede med en stor banket på Fredensborg slot, hvor Stephens atter var at finde blandt gæsterne. Jarvis afslutter sin beskrivelse af den engelske kirkes tilblivelseshistorie således:

"The Building Committee completed its labours and handed the Church over as a going concern in November 1887, after an existence of 34 years; in truth a job well and truly done. Just imagine the feelings of that little band, several of which had worked, if not from the beginning, like Prof. Stephens, at least for many years; - alas that the old Chaplain, Mr. Ellis, should pass away, only four days before the Church was consecrated." (Jarvis, s. 92).

Inde i kirken er der et antal mindeplader og lignende over nogle af de personer, der har spillet en afgørende rolle i menighedens og kirkens liv. Heriblandt finder vi "The Stephens Memorial Window", til minde om professor George Stephens og hans kone. Om dette siger Jarvis:

"The subject is 'Bearing the Cross'. Dedicated on April 17, 1898. The Mural Brass bears the words: To the Glory of God, and in loving memory of George Stephens D.Litt.Camb., F.S.A. Lond. \& Edinb. Professor of the English language and literature in the University of Copenhagen during 42 years. Born Dec. 13. 1813, died August 9, 1895, and of his beloved wife Marie born July 24,1808, died March 17, 1896. This window is dedicated by their children, nephews and nieces. 
'The memory of the Just is Blessed' Prov.X 7." (Jarvis, s. 139).

I det sidste kapitel (XIII) af sin bog fremmaner Jarvis så at sige forskellige personer med tilknytning til den historie, han netop har fortalt. Generelt siger han om dem:

"One seems almost to know them, to imagine what they were like, and to regard them with affection; nor can one help but be impressed by the long-continued and considerable labour of love many of these men gave in the service of their fellows." (Jarvis, s. 167).

Derpå går han over til at beskrive dem én for én, og om Stephens har han følgende at sige:

"Professor George Stephens F.S.A. Lond. Edin. and Cambridge. Commander of the Order of the Wasa and Knight of the Northern Star (Sweden); Knight of St. Olaf (Norway); Professor of the English Language and Literature at Copenhagen University; Knight of Dannebrog and Dannebrogsmand (Denmark) etc. He resided in Scandinavia for 60 years and lived to celebrate his golden and diamond wedding anniversaries. He was born in 1813 and began his Scandinavian researches in Stockholm. He published several learned treatises, but his greatest work, on which he expended an enormous amount of labour, is "The Old Runic Monuments of Scandinavia and England". Another voluminous work of research was his uncompleted lexicon of the old Northumbrian dialect. He corresponded, mostly in Latin, with philosophers all over Europe and the East. He was high-minded and noble, truth-loving and God-fearing, greatly beloved and esteemed ... Can you not see the staunch old man, when the Church was completed, walking down to Matins, in the pleasant September sunshine; he pauses to admire the picture made by the beautiful building in its ideal setting, and humbly conscious that he, more than any one man, had called it into being, raises his hat in the fulness of his joy and gratitude and murmurs a word of Praise. He would be 74 years of age then - he was 40 when he got the members of the first modest Building Committee together." (Jarvis, s. 169-70).

I ovenstående har jeg forsøgt at tegne et portræt af George Stephens, en person fra fortiden, som er valgt som emne, fordi han var lærer i engelsk i Danmark. Med denne artikel udfyldes herved en lakune, således at man kan sige, at de vigtigste og mest interessante engelsklærere her i landet - ved Universitetet og andre steder - nu er beskrevet, enten af mine kolleger eller mig selv, oftest i samarbejde med Hanne 
Lauridsen. Kronologisk er F. Bolling (født i det 17. århundrede) den første og C.A. Bodelsen (foreløbig) den sidste. Bortset fra nogle af de seneste synes det karakteristisk for alle disse lærere, at de personligt var ret særprægede på den ene eller den anden måde. Nogle rejste den halve klode rundt på jagt efter eventyr, andre fandt det eventyrlige hjemme ved at opføre sig eller klæde sig opsigtsvækkende, og vi har endda også blandt dem fundet en meget dygtig litterær bedrager. Man kan undre sig over, hvorfor studiet af og undervisningen i engelsk i ældre tid tilsyneladende virkede tiltrækkende på så mange særprægede personligheder. Var det eventuelt, fordi det blev anset for "eksotisk" at beskæftige sig med dette sprog snarere end med tysk og fransk - dengang mere nyttige og populære fremmedsprog i Danmark?

Det er næppe nødvendigt at tilføje, at situationen er ganske anderledes i dag; engelsk er populært som ingensinde før, antallet af engelsklærere er særdeles stort, og størstedelen af os er, som folk er flest.

Bibliografi:

Axelsen, J.: Leksikografi og excentricitet; Thorleifur Gudmundsson Repp, en islandsk leksikograf. i: Magasin for Det kongelige Bibliotek 9. årg. Nr.4. 1995 (s. 40-55).

Bobé, L.: Livsdagen lang. Kbh. 1947.

Jarvis, A.C.: Some Account of The English Episcopal Church in Denmark. København: The Committee of St. Alban's Church, 1934.

Jespersen O.: En sprogmands levned. Kbh. 1938. Kabell, I.: Thomas Christopher Bruun, 17501834. The First Professor of English in Denmark. i: Pre-Publications of the English Department. Nr. 72. Odense. 1994.

Kabell, I.: A Property in Central Copenhagen in the Middle of the 19th Century - a church, a school, a family - constituting an example 'en miniature' of Danish-English relations. i: PrePublications of the English Department. Nr. 80. Odense. 1995.

Nielsen, J.E.: Engelsk sprog og litteratur. i: Kobenhavns Universitet 1479-1979, bind IX, udg. af Povl Johs. Jensen. Kbh. 1979.
Stephens, G.: Candidat L.F.A. Wimmer om de oldnordiske Runeindskrifter. i: Aarboger for Oldkyndighed og Historie. Kbh. 1867

Wimmer, L.F.A.: De ældste nordiske runeindskrifter. i: Aarboger for Oldkyndighed og Historie. Kbh. 1867.

Biografiske leksika:

Dansk Biografisk Lexikon tillige omfattende Norge for Tidsrummet 1537-1814, udg. af C.F. Bricka. Bind XVI. Kbh. 1902.

Dansk Biografisk Leksikon, udg. af P. Engelstoft et al.Bind XXII. Kbh. 1942.

Supplement til Almindeligt Forfatter-Lexicon for Kongeriget Danmark med tilhorende Bilande..., af Thomas Hansen Erslew. Bind III. Kbh. 1964 (genoptryk).

Svenska män og kvinnor. Biografisk Uppslagsbok. Bind VII. Stockholm. 1954.

Svensk Uppslagsbok. Bind XXVII. Malmö. 1953. 
Noter

1 Jvfr. Inge Kabell: Thomas Christopher Bruun, 1750-1834. The First Professor of English in Denmark.

2 Blandt ansøgerne var den noget kontroversielle Thorleifur Gudmundsson Repp (1794-1857), som blev dybt skuffet over ikke at komme i betragtning. Jvfr. Jens Axelsen: Leksikografi og excentricitet; Thorleifur Gudmundsson Repp, en islandsk leksikograf.

3 De biografiske oplysninger om Stephens stammer i det væsentlige fra svenske og danske biografiske leksika, nærmere angivet $\mathrm{i}$ bibliografien, og fra Jørgen Erik Nielsen: Engelsk sprog og litteratur.

4 Angående titler se T.H.Erslew, Supplement til Almindeligt Forfatter-Lexicon..., bind 3, s. 268-79.

5 - hvilket han vel må have fået officiel tilladelse til.

6 Den danske udgave, Angelsaxisk Sproglere tillige med en kort Lasebog daterer sig fra 1813; i 1830 blev den fulgt op af en engelsk version.

7 I sin selvbiografi, Af en sprogmands levned, 1938, s. 70, har Jespersen flg. kommentar hertil: "Som privatdosent holdt jeg øvelser over Sweets Anglo-Saxon Reader, hvorved videnskabeligt engelsk sprogstudium blev indført ved vort universitet..." - unægtelig en noget barsk bemærkning!

8 Disse uformelle arrangementer blev endda annonceret i lektionskatalogen. Indtil 1856 var Stephens' adresse "Vesterbro 44B" og siden "Gammel Kongevej 50, Hjørnet af Bianco Lunos Allee".

9 - som findes på Det kongelige Bibliotek.

10 Ludvig Wimmer, dr.phil. (1839-1920). Docent i sammenlignende sprogvidenskab ved Københavns Universitet, 1871, docent i nordisk filologi samme sted, 1876 og professsor i nordiske sprog, 1886-1910, atter samme sted. Datidens ledende runolog og grundlægger af den moderne runeforskning. Hans hovedværk, De danske Runemindesmarker - med illustrationer - udkom 1893-
1908 og var i mange år hovedkilden til studiet af den nordiske fortid, indtil det forældedes blandt andet på grund af ny teknik.

11 Deres uenighed synes først og fremmest at have rod i den kendsgerning, at Stephens forfægtede, at engelsk er et skandinavisk sprog, mens Rask, Wimmer m.fl. inkluderede det $\mathrm{i}$ de vestgermanske sprog - altså, f.eks. ligesom tysk. Senere tiders forskere har uddybet og bekræftet, at Wimmer havde ret og Stephens uret, ligesom Stephens jo heller aldrig fandt den "Scando-English dialect", som han oprindelig var draget ud for at opspore.

12 Til eksaminationen brugte Stephens en tekst af Marryat, The Children in the New Forest, og eksaminanderne blev bedt dels om at oversætte et afsnit dels om at besvare en række grammatiske spørgsmål i forbindelse med teksten.

13 Når Otto Jespersen citeres, sker det naturligvis med hans egen specielle stavemåde. Der er således ikke tale om trykfejl i de her gengivne citater.

14 Jvfr. Inge Kabell, A Property in Central Copenhagen in the Middle of the 19th Century a church, a school, a family - constituting an example "en miniature" of Danish-English relations.

15 Den primære kilde til St.Alban's Church' byggehistorie er Alec.C. Jarvis, Some Account of The English Episcopal Church in Denmark, 1934, og den resterende del af denne artikel vil for en stor del hente sit stof herfra - enten omskrevet på dansk - eller, når det føles rimeligt, som direkte uoversatte citater, f.eks. i forbindelse med breve.

16 Det var også Stephens, der gav forslag til kirkens navn: "Professor Stephens had ... suggested that the church be named after Saint Alban, who was the Proto-Martyr of England and held in great veneration in Denmark..." (Jarvis s. 79).

17 Mr. Ellis, Mr. Repp, George Stephens, John McCormick (of Copenhagen) and George Fenwick (of Elsinore).

18 For eksempel, Stephens' datter, fru Ingeborg Friis. 